\title{
MELENGKAPI ANALISA TEORI AKSES DENGAN PENDEKATAN KOLABORATIF PADA KONTEKS PROGRAM PERHUTANAN SOSIAL: STUDI KASUS LEMBAGA MASYARAKAT DESA HUTAN (LMDH) RAWA SAKTI, PEMALANG \\ COMPLEMENTING ACCESS THEORY ANALYSIS BY COLLABORATIVE APPROACH ON SOCIAL FORESTRY IMPLEMENTATION CONTEXT: CASE STUDY ON THE RAWA SAKTI FOREST COMMUNITY VILLAGE IN PEMALANG
}

\author{
${ }^{* 1}$ Dicky Rachmawan, ${ }^{* 2}$ Francisia Saveria Sika Ery Seda, ${ }^{* 3}$ Robert Siburian \\ ${ }^{1}$ Program Studi Pascasarajana Sosiologi \\ Fakultas Ilmu Sosial dan Ilmu Politik Unvirsitas Indonesia \\ ${ }^{2}$ Departemen Sosiologi \\ Fakultas Ilmu Sosial dan Ilmu Politik Unvirsitas Indonesia \\ ${ }^{3}$ Pusat Penelitian Masyarakat dan Budaya \\ Lembaga Ilmu Pengetahuan Indonesia
}

Submitted:27-04-2021 Revised: 06-08-2021 Accepted: 09-08-2021

\begin{abstract}
The shift of the forest management paradigm in Indonesia in this recent time has given more space for people that align with the Indonesian Government to elevate well-being at once to conserve forest through Social Forestry Program. One model group from 6.411 forest communities that manage forest is Forest Village Communuty or Lembaga Masyaraakat Desa Hutan (LMDH) of Rawa Sakti. This paper aims to describe the structure-process of social forestry program implementation in LMDH Rawa Sakti which uses access theory that is complemented by the collaborative approach. The qualitative approach with descriptive analysis in the case study isconductedthrough depth interviews (consist of the management and members of LMDH Rawa Sakti, middleman, village officer, and coffee entrepreneur), observation, and focus group discussion. The result shows that negotiation and social relation access is the essential access that can influence five other forms of SRAM by Theory of Access that need to be examined by the collaborative approach elements, especially at accountability, communication, involvement, and equity to identify elite capture. In the end, the elite capture causes a lack of contribution and cooperation as a group to achieve social forestry program goal.
\end{abstract}

Keywords: Access Theory; Collaborative Approach; Social Forestry; LMDH Rawa Sakti.

*Corresponding author:_dickylipi@gmail.com

Copyright@ 2021 THE AUTHOR (S). This article is distributed under a Creative Commons Attribution-Share Alike 4.0 International license. Jurnal Kawistara is published by the Graduate School of Universitas Gadjah Mada. 


\section{ABSTRAK}

Perubahan paradigma pengelolaan hutan di Indonesia kini telah memberikan ruang yang lebih bagi masyarakat sejalan dengan tujuan pemerintah untuk meningkatkan kesejahteraan sekaligus menjaga kelestarian hutan melalui Program Perhutanan Sosial. Salah satu kelompok model dari 6.411 kelompok yang mengelola hutan adalah Komunitas Desa hutan atau Lembaga Masyarakat Desa Hutan Rawa Sakti. Makalah ini bertujuan untuk menggambarkan dinamika struktur-proses pengimplementasian program perhutanan sosial di LMDH Rawa Sakti menggunakan teori akses yang dilengkapi dengan pandangan kolaboratif. Pendekatan kualitatif dengan analisis deskriptif dalam bentuk studi kasus dilakukan dengan mewawancarai 30 informan (terdiri dari pengurus dan anggota LMDH Rawa Sakti, tengkulak, perangkat desa, dan pengusaha kopi), obersevasi, dan diskusi kelompok terbatas. Hasil dari penelitian ini menunjukan bahwa akses negosiasi dan hubungan sosial (NHS) adalah akses esensial yang memiliki pengaruh pada lima jenis akses SRAM dari teori akses yang perlu dilihat dari unsur pandangan kolaboratif khususnya pada unsur akuntabilitas, komunikasi, pengikutsertaan dan keadilan untuk mengidentifikasi terjadinya elite capture. Terjadinya elite capture pada akhirnya menyebabkan rendahnya kontribusi dan kurang berjalannya kelompok dari tujuan program perhutanan sosial.

Kata Kunci: Teori akses; Pendekatan Kolaborasi; Perhutanan Sosial; LMDH Rawa Sakti.

\section{PENGANTAR}

Pengelolaan hutan telah bergeser dalam lima dekade terakhir (Nath, Jashimuddin dan Inoue, 2016; Wright et al., 2016; Moeliono et al., 2017) karena sistem pengelolaan hutan yang sentralistik dianggap telah gagal dalam mensejahterakan masyarakat dimana $40 \%$ dari 2,5 miliar petani dunia tergolong sangat miskin dan menggantungkan hidupnya dari sumber daya hutan (Kaskoyo et al., 2017; Moeliono et al., 2017; UNESA, 2019; Wright et al., 2016)

Kini pengelolaan hutan cenderung memberikan ruang bagi komunitas atau lebih mengarah pada desentralisasi pengelolaan yang dilakukan oleh masyarakat untuk mensejahterakan masyarakat di sekitar hutan (Nath, Jashimuddin dan Inoue, 2016; Voo, Mohammed dan Inoue, 2016; García-López dan Antinori, 2018).
Pengelolaan hutan berbasis komunitas diharapkan dapat lebih efektif dengan asumsi masyarakat lokal lebihmengetahuikondisi hutan yang ada di sekitarnya dan dapat mengelolanya lebih baik lagi (Wright et al., 2016). Berbagai Pilot project yang ditemukan di beberapa negara yang mendesentralisasikan pengelolaan hutan kepada masyarakat contohnya seperti di Bangladesh, Mexico, Malaysia, termasuk juga Indonesia (Nath, Jashimuddin and Inoue, 2016; Voo, Mohammed dan Inoue, 2016; García-López and Antinori, 2018) menjadi perhatian penting dalam studi tata kelola hutan

Pada konteks Indonesia pengelolaan hutan antara tahun 1967-1998 masih memiliki arah dan kecenderungan dengan penguasaan oleh para pemilik modal dengan kegiatan yang bersifat ekstraktif yang cenderung meminggirkan masyarakat lokal (Noveria et al., 2005; Hidayat, 2015; Royer, Noordwijk dan Roshetko, 2018). Sampai tahun 2015 ketimpangan pada luas pengelolaan kawasan hutan masih sangat tinggi antara pemilik modal yang menguasai 41,33 juta hektar dan masyarakat hanya menguasai 1,7 juta hektar (Kuncoro dan Cahyani, 2018; Pambudi, 2020). Padahal diperkirakan \pm 91 juta orang dari 83.724 desa atau kelurahan yang ada di dalam atau sekitar hutan di Indonesia merupakan komunitas yang cenderung miskin (BPS, 2020; Fisher et al., 2018; Setiajiati et al., 2019).

Pengelolaan hutan berbasis masyarakat baru muncul setelah tahun 1980-an dengan istilah Pembinaan Masyarakat Desa Hutan (PMDH) yang terus berkembang dan kini dikenal dengan istilah program perhutanan sosial (selanjutnya disebut program PS) (Wright et al., 2016; Moeliono et al., 2017; Firdaus, 2018; Fisher et al., 2018; Susilo dan Nairobi, 2019). Program PS memberikan ruang bagi masyarakat untuk mengelola hutan sebagai peningkatan partisipasi komunitas (Nath, Jashimuddin dan Inoue, 2016; Kelly, 2018; Kuncoro dan Cahyani, 2018; Essougong, Foundjem-Tita and Minang, 2019) serta meningkkatkan kesejahteraan masyarakat (Kuncoro dan Cahyani, 2018; Asmin et al., 2019; Rakatama dan Pandit, 2020).

Lima tahun Program PS telah berjalan dengan menerbitkan 6.411 sertifikat kelompok 
(DS, 2020), dimana pada konteks implementasi progam PS di Pulau Jawa bentuk skema yang cenderung dilakukan adalah bentuk "kemitraan" (BPS, 2020; Rachmawan, 2020). Salah satu kelompok model program PS bentuk kemitraan di Indonesia adalah LMDH Rawa Sakti (Rachmawan, 2020).

Penelitian yang kajian tentang program PS, telah banyak dilakukan seperti penelitian yang mengkaji dampak program PS menemukan berbagai variasi dampak baik positif atau negatif dari program PS (Rakatama \& Pandit, 2020; Santika et al., 2019). Dampak positif ialah kejelasan hak pengelolaan kawasan hutan (Nurrochmat et al., 2019) sampai peningkatan pendapatan (Kuncoro \& Cahyani, 2018). Pada sisi lainnya, terdapat penelitian yang melihat dampak atau mengidentifikasi faktor negatif seperti permasalahan sektoral disertai buruknya partisipasi (Pambudi, 2020; Suparno et al., 2018), buruknya akuntabilitas yang diakaitkan dengan kebermanfaatan yang lebih cenderung diambil oleh elit komunitas atau kelompok atau elite capture (Moeliono et al., 2017; Essougong, Foundjem-Tita dan Minang, 2019; Qurniati et al., 2019; Rakatama dan Pandit, 2020). Lebih lanjut elite capture ini yang justru melemahkan kelompok (Essougong et al., 2019; Moeliono et al., 2017; Qurniati et al., 2019) yang perlu diatasi dengan pembagian otoritas dalam partisipasi dan komunikasi (Asmin et al., 2019).

Berbeda dari penelitian sebelumnya, tujuan dari artikel ini adalah untuk menggambarkan dinamika struktur-proses dari interaksi antar pihak dalam pengimplementasian program PS di LMDH Rawa Sakti melalui teori akses (Ribot, Jesse \& Peluso, Nancy, 2003) yang dilengkapi pendekatan kolaboratif atau CA (Collaborative Approach) (Nath, Jashimuddin dan Inoue, 2016; Wright et al., 2016; Moeliono et al., 2017; Sardjono dan Inoue, 2017; Kelly, 2018; Wulandari dan Inoue, 2018; Pujo et al., 2018; Royer, Noordwijk dan Roshetko, 2018; Asmin et al., 2019; Massiri et al., 2020; Myers dan Hansen, 2020). Karena memang terdapat arena baru bagi teori akses yang dapat dikembangkan dalam mengkaji bentuk kolaborasi (Peluso \& Ribot, 2020).

CA digunakan untuk melengkapi aspekaspek yang kurang dijelaskan oleh teori akses di dalam menganalisis dinamika implementasi program perhutanan sosial. Kemudian, penggunaan aplikasi Nvivo dan Microsoft Excel dilakukan untuk menginventarisir data temuan yang kemudian dilakukan perhitungan agregat dengan hasil akhir yang dirangkum dalam sebuah skema teori akses yang dilengkapi dengan CA. Perhitungan agregat di sini merefleksikan tingkat kedalaman data yang didapatkan.

Artikel ini menggunakan pendekatan kualitatif dengan analisis deskriptif dalam bentuk studi kasus dengan teknik pengambilan data yaitu wawancara mendalam, dengan 30 informan (pengurus dan anggota LMDH Rawa Sakti, tengkulak, perangkat desa, dan pengusaha kopi), obersevasi, dan focus group discussion. Kegiatan penelitian ini dilakukan pada akhir Januari hingga minggu ketiga bulan Febuari 2021 khususnya di Desa Gambuhan, Kecamatan Pulosari, Kabupaten Pemalang.

\section{PEMBAHASAN \\ Teori Akses: Kekuatan dan Kritik}

Teori akses telah digunakan untuk menelaah dan memetakan permasalahan dalam pemanfaatan pengelolaan sumberdaya alam termasuk dalam konteks hutan (Peluso \& Ribot, 2020) yang erat kaitannya dengan pandangan struktur dan agensi antar para pihak yang terlibat (Ribot, Jesse dan Peluso, Nancy, 2003; Shohibuddin, 2018; Myers dan Hansen, 2020). Lebih lanjut teori akses juga dapat menggambarkan perubahan sosial (Ribot, Jesse \& Peluso, Nancy, 2003).

Sebagai salah satu teori dalam ilmu sosial, teori akses bertumpu pada hubungan sosial sebagai dasar dalam pembahasannya yang menganalisis 1) pengidentifikasian arus manfaat dan kepentingan dalam hubungan sosial, 2) mekanisme yang digunakan aktor untuk memperoleh, mengontrol atau memelihara manfaat dan distribusinya, dan 3) hubungan kekuasaan khususnya mekanisme akses (Ribot, Jesse \& Peluso, Nancy, 2003). Disamping terdapat kapasitas aktor sebagai aspek yang dapat mempengaruhi kemampuan untuk mengakases suatu jenis sumberdaya seperti aspek legal, ekonomi dan budaya (Ribot, Jesse dan Peluso, Nancy, 2003) 
Lebih lanjut dalam menganalisis akses ini Ribot dan Peluso (2003) membagi beberapa jenis kapasitas dengan istilah structural and relational access mechanism (selanjutnya disebut SRAM) yang terdiri dari akses 1) teknologi (Tec), 2) modal (Cap), 3) pasar (Mrkt), 4) tenaga kerja (Labour), 5) pengetahuan (Inf), 6) otoritas (Auth), 7) identitas (Id), dan 8) negosiasi dan hubungan sosial (NHS).

Pada penjabarannya Ribot dan Peluso (2003) menjelaskan bahwa akses teknologi menekankan pada pemanfaatan cara, alat atau pengetahuan. Lalu akses modal menekankan pada kemampuan finansial bagi satu pihak untuk mengakses atau memelihara suatu sumberdaya. Akses terhadap pasar dijelaskan sebagai kemampuan untuk memanfaatkan sumber daya dengan banyak cara yang dipengaruhi pada akses pihak tertentu kepada pasar. Akses terhadap pasar mensyaratkan akses modal, otoritas, hubungan sosial.

Pada gilirannya akses tenaga kerja memiliki persyaratan yang lebih dari akses terhadap pasar, karena akses ini memerlukan akses modal dan akses pasar secara bersamaan. Tanpa ada kehadiran kedua akses tersebut seseorang atau satu pihak tidak memiliki akses tenaga kerja. Kemudian, akses pengetahuan menitikberatkan pada penguasaan terhadap pengetahuan dan informasi yang juga dapat bersumber dari nilai-nilai kepercayaan yang ada di dalam suatu kelompok. Nilai-nilai kepercayaan ini bisa sangat beragam dan sangat kontekstual.

Tabel 1.

Kritik terhadap Teori Akses

\begin{tabular}{l|l}
\hline \multicolumn{1}{c|}{ Penulis (Tahun) - Lokasi } & \multicolumn{1}{c}{ Hal yang Dikuatkan } \\
\hline $\begin{array}{l}\text { Calderon Contreras (2011) - } \\
\text { Reformasi Agraria di Meksiko }\end{array}$ & Perlu melihat pengaruh institusi dalam mentransformasi hak \\
\hline $\begin{array}{l}\text { Hall, Hirsch dan Li (2011) - } \\
\text { Reformasi Agraria di Asia } \\
\text { Tenggara }\end{array}$ & $\begin{array}{l}\text { SRAM kurang menjelaskan ekslusi dalam empat bentuk: 1) } \\
\text { regulasi, 2) force (kekuasaan di luar aspek legal), 3) pasar, dan 4) } \\
\text { legitimasi }\end{array}$ \\
\hline Rao (2008) & $\begin{array}{l}\text { Akses dengan self-esteem, personhood, self-worth yang dapat } \\
\text { menambahkan kekuasaan (kapabilitas) }\end{array}$ \\
\hline Sikor dan Lund (2009) & $\begin{array}{l}\text { Berbicara tentang akses tidak hanya melihat bagaimana kesejahteraan } \\
\text { terdistribusi, tetapi proses institusi, konsolidasi dalam membangun } \\
\text { negara. Keterhubungan antara properti dan otoritas (kontrak) }\end{array}$ \\
\hline Koch (2008) & $\begin{array}{l}\text { Teori akses kurang konsisten pada mekanis konseptualisasi } \\
\text { mekanisme akses yang kurang dapat membedakan antara } \\
\text { struktur dan relasi. Teori akses kurang jelas menyebutkan sumber } \\
\text { kekuasaan karena disebutkan kekuasaan adalah produk negosiasi } \\
\text { atau sesuatu yang diproses secara individual }\end{array}$ \\
\hline
\end{tabular}

Sumber: Myers dan Hansen (2020).

Lalu akses otoritas adalah akses yang mendefinisikan sumber kekuasaan didasarkan kekuatan hukum, nilai-nilai yang dipercaya dalam suatu masyarakat (seperti adat-istiadat), atau kesepakatan antar pihak di dalam suatu konteks masyarakat. Pada sisi lainnya, terdapat akses identitas yang menitik beratkan pada latar belakang satu pihak misalnya keanggotaan di dalam suatu komunitas. Terakhir unsur dari SRAM adalah akses negosiasi dari hubungan sosial (NHS) yang disebutkan bahwa hubungan sosial, kepercayaan, juga mempengaruhi bagaimana seseorang atau satu pihak mendapatkan manfaat.

Pada perkembangannya teori akses telah digunakan oleh 1.144 tulisan ilmiah yang kebanyakan mengkaji tentang geografi (31\%), $\operatorname{tanah}(25 \%)$, hutan (22\%) dan kesejanteraan (18\%) (Myers dan Hansen, 2020). Namun dari sekian banyak tulisan ilmiah yang telah dilakukan hanya sekitar 3,5\% saja yang mengkritik teori akses, seperti beberapa penelitian yang ada pada tabel 1. Teori akses kurang menjelaskan sumber kekuasaan menurut Koch di tahun 2008, kurang melihat proses institusi dalam 
bentuk kontrak menurut Sikor dan Lund di tahun 2009, kurang melihat pengaruh institusi dalam mentransformasi hak menurut Contreras di tahun 2011, dan kurang menjelaskan ekslusi khususnya dalam bentuk kekuatan atau force menurut Hall, Hirsch dan Li di tahun 2011 (Myers \& Hansen, 2020: 149-160)
Lebih lanjut menurut Myers dan Hansen (2020) menyebutkan bahwa teori akses dikritik karena terlalu menekankan aspek "individualisme"-nya. Seperti contohnya yang disebutkan Ribot dan Peluso (2003:170), “... Akses otoritas membentuk kemampuan individu untuk memanfaatkan sumberdaya...".

Tabel 2.

Perbandingan Prinsip CA dalam Pengelolaan Hutan

\begin{tabular}{|c|c|c|c|}
\hline CBFM & CFG & SL & PS \\
\hline $\begin{array}{l}\text { 1. Sistem pengelolaan } \\
\text { hutan; } \\
\text { 2. Peningkatan } \\
\text { kualitas kehidupan } \\
\text { 3. Peningkatan } \\
\text { kualitas } \\
\text { lingkungan; } \\
\text { 4. Pengakuan dan } \\
\text { menghormati } \\
\text { perbedaan } \\
\text { 5. Mendukung proses } \\
\text { kolaboratif; dan } \\
\text { 6. Didukung } \\
\text { oleh kebijakan } \\
\text { pemerintah }\end{array}$ & $\begin{array}{l}\text { 1. Derajat otonomi lokal; } \\
\text { 2. Kejelasan batasan } \\
\text { sumberdaya; } \\
\text { 3. Graduated } \\
\text { membership; } \\
\text { 4. Komitmen; } \\
\text { 5. Distribusi yang adil; } \\
\text { 6. Sistem pengawasan } \\
\text { dua cerita } \\
\text { (komunikasi); } \\
\text { 7. Sistem sanksi dua } \\
\text { cerita; } \\
\text { 8. Mekanisme penge- } \\
\text { lolaan konflik; dan } \\
\text { 9. Pembangunan } \\
\text { kepercayaan }\end{array}$ & $\begin{array}{l}\text { 1. Atmosfir yang } \\
\text { egalitarian atau atmosfir } \\
\text { yang merangkul } \\
\text { semua pihak di dalam } \\
\text { prosesnya; } \\
\text { 2. Kegiatan rutin yang } \\
\text { mengikutsertakan } \\
\text { seluruh pihak terkait di } \\
\text { dalam komunitas; } \\
\text { 3. Fasilitasi yang didukung } \\
\text { baik pemerintah atau } \\
\text { pihak luar untuk; } \\
\text { 4. Meningkatkan } \\
\text { pengetahuan dan } \\
\text { merangkul pengetahuan } \\
\text { yang ada atau muncul. }\end{array}$ & $\begin{array}{l}\text { 1. Kolaborasi atau } \\
\text { partnership; } \\
\text { 2. Pemahaman } \\
\text { bagi setiap } \\
\text { kelompok; } \\
\text { 3. Berbagi } \\
\text { manfaat dan } \\
\text { biaya; } \\
\text { 4. Keseimbangan } \\
\text { manfaat } \\
\text { ekonomi dan } \\
\text { lingkungan; } \\
\text { 5. Legalitas atau } \\
\text { kepastian } \\
\text { hukum }\end{array}$ \\
\hline
\end{tabular}

Sumber: Sardjono dan Inoue (2017), Pujo et al. (2018) Wulandari dan Inoue (2018).

Padahal menurut Pujo et al. (2018) dalam konteks program PS yang cenderung dilihat sebagai suatu kesatuan komunitas pada masyarakat yang mengelola kawasan hutan yang memerlukan transformasi kapasitas dari komunitas dan bukan menekankan pada individualisme orang-orang yang ada di dalamnya. Maka dari itu terdapat aspek-aspek yang kurang dilihat oleh teori akses yang disampaikan oleh Ribot dan Peluso (2003) yang dapat dilengkapi dengan collaborative approach sebagai aspek non-SRAM.

\section{Collaborative Approach (CA) untuk melengkapi analisis Teori Akses}

Kompleksnya pengelolaan hutan mengarah pada perlunya konsolidasi tidak hanya pada satu kelompok/komunitas tetapi juga berbagai aktor yang terlibat di dalamnya (Mohammed, Inoue dan Shivakoti, 2017) yang sejalan dengan CA untuk menciptakan kesepakatan dan kebermanfaatan sosioekonomik (Wright et al., 2016).
Terdapat beberapa istilah dari pengelolaan hutan berbasis CA yaitu Community Based Forest Management (CBFM) (Nath, Jashimuddin dan Inoue, 2016; Pujo et al., 2018; Asmin et al., 2019), Collaborative Forest Governance (CFG) (Sardjono dan Inoue, 2017) atau Collaborative Forest Management (CFM) (Mohammed et al., 2017; Voo et al., 2016), Social Learning (Wulandari \& Inoue, 2018) dan Social Forestry atau Perhutanan Sosial (PS) (Asmin et al., 2019; Fisher et al., 2018; Kuncoro \& Cahyani, 2018; Pujo et al., 2018). Tabel 2 merupakan perbandingan prinsip dari keempat istilah CA dalam pengelolaan hutan

Pada dasarnya keempat istilah dari CA dalam pengelolaan hutan memiliki aspek mendasar yaitu kolaborasi berbagai pihak dalam mengelola hutan dalam rangka meningkatkan kesejahteraan masyarakat.

Berdasarkan tabel 2, maka terdapat aspek yang kurang dijelaskan Ribot and Peluso (2003) dalam SRAM terkait dengan kapasitas komunitas seperti atmosfir egalitarian atau merangkul semua pihak sebagai sebuah 
proses dalam SL atau sistem pengawasan dua cerita (komunikasi) dalam CFG. Lebih spesifik dalam melihat dinamika hubungan strukturproses penting untuk melihat pola komunikasi (Essougong et al., 2019; Massiri et al., 2020) yang secara teknis dilihat dari kegiatan rutin pengikutsertaan dalam membuat keputusan untuk meningkatkan rasa kebersamaan (Wulandari \& Inoue, 2018). Komunikasi yang dimaksud adalah komunikasi dua arah yang dapat menstimulus anggota untuk turut aktif berkontribusi di dalam kelompok (Asmin et al., 2019; Kelly, 2018)

Kemudian, aspek penting lainnya yang kurang dijelaskan oleh teori akses adalah transparansi dan akuntabilitas dalam proses partisipasi (Fisher et al., 2018; Mohammed et al., 2017). Kejelasan informasi ini mengarah pada kejelasan aspek-aspek teknis yang mengikutinya dan mengarah pada pembuatan keputusan yang maksimal dari distribusi kekuasaan serta distribusi manfaat sekaligus peningkatan kapasitas hingga ke tingkat anggota (Fisher et al., 2018; Kelly, 2018; Pujo et al., 2018; Royer et al., 2018; Voo et al., 2016).

Lebih lanjut penyaluran informasi yang dua arah disertai dengan akuntabilitas dan distribusi manfaat akan mendorong kebersamaan atau dapat disebut kohesi sosial sebagai suatu kesatuan kelompok (Weissberg et al., 2018) dan rasa saling percaya atau trust (Kelly, 2018; Pujo et al., 2018).

Kemudian aspek yang kurang dijelaskan oleh Ribot and Peluso (2003) adalah keadilan, meskipun tujuan dari teori akses adalah menguatkan keadilan dari permasalahan pemanfaatan sumber daya alam (Peluso \& Ribot, 2020). Distribusi yang adil yang dirasakan tidak hanya pada tingkat kelompok tetapi juga perlu digali lebih lanjut pada tingkat anggota (Asmin et al., 2019; Essougong et al., 2019; Fisher et al., 2018; Kaskoyo et al., 2017; Kelly, 2018; Mohammed et al., 2017; Nath et al., 2016; Royer et al., 2018; Weissberg et al., 2018)

Aspek keadilan ini yang berbanding terbalik dengan elite capture yang dapat diatasi dengan partisipasi melalui komunikasi dan kontribusi yang adil (Asmin et al., 2019). Berdasarkan dari uraian yang dijelaskan di atas, maka CA dapat melengkapi analisis teori akses melalui konsep partisipasi yang dilihat pada aspek komunikasi dua arah dan terekspos dalam kegiatan rutin yang mengikutsertakan anggota kelompok, akuntabilitas dalam penyebaran informasi, dan keadilan dalam distribusi manfaat yang dirasakan oleh para anggota dari LMDH Rawa Sakti. Bagian selanjutnya adalah penjelasan tentang analisis SRAM yang dilengkapi konsep Partisipasi dari CA.

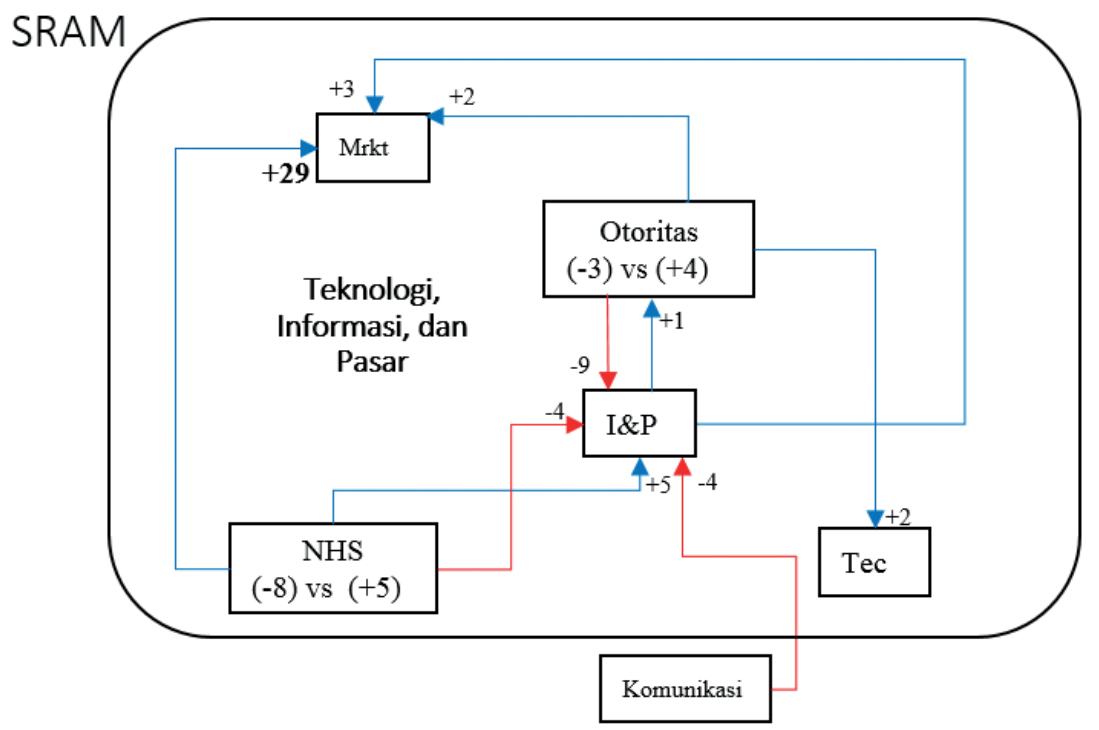

Gambar 1.

Pemetaan Agregat Akses Teknologi (Tec), Informasi dan Pengetahuan (I\&P), dan Pasar (Mrkt) Sumber: data primer yang diolah penulis, tahun? 


\section{Analisis Teori Akses (SRAM) yang dilengkapi CA (non-SRAM) berdasarkan Agregat}

Pada bagian ini akan dijabarkan komponen dari SRAM dan non-SRAM, penjabaran akan menjelaskan bahwa satu jenis komponen dipengaruhi oleh komponen lainnya, dan komponen tersebut mempengaruhi komponen lainnya. Setelah bagian ini akan digambarkan skema dari analisis SRAM yang dilengkapi oleh komponen CA (non-SRAM). Sedikit berbeda dengan yang disebutkan oleh Ribot dan Peluso (2003). Angka-angka yang dimunculkan dalam gambar adalah agregat dari SRAM/non-SRAM pada skema khususnya berada di dekat tanda panah biru yang berdampak positif dengan nilai $(+)$ atau negatif dengan panah berwarna merah dengan nilai (-).

\section{Akses Teknologi, Informasi, dan Pasar}

Gambar 1, adalah gambar yang menelaah akses teknologi (Tec), informasi dan pengetahuan (I\&P), dan Pasar (Mrkt). Berdasarkan gambar tersebut dapat dilihat bahwa akses teknologi dengan agregat (+2) khususnya alat terkait produksi kopi adalah akses paling sedikit agregatnya yang didapatkan oleh LMDH Rawa Sakti. Karena hanya satu pihak tertentu tertentu saja yaitu pengusaha kopi yang menjadi anggota dari Kelompok Usaha Perhutanan Sosial (KUPS) di LMDH Rawa Sakti yang mendapatkan bantuan mesin dari pemerintah daerah (akses otoritas) untuk memberikan dan menganggarkan pengadaan alat, seperti kutipan berikut “... Ini mesin saya dapat dari Dinas Pertanian dan Dinas Koperindag..." (Wawancara INF34 yang dilakukan pada tanggal 2 Februari 2021 pada pukul 11.10-12.15 WIB).

Terkait dengan akses I\&P, maka dapat dilihat agregat tertinggi justru bersifat negatif yaitu -9. Nilai ini muncul justru dari akses otoritas yang sangat disayangkan justru dilakukan oleh pengurus LMDH Rawa Sakti itu sendiri pada buruknya akses untuk membuka izin usaha oleh anggota lain di LMDH Rawa Sakti (-3), pelatihan yang diikuti oleh orang terdekat pengurus (-2), dan ketidakjelasan arahan informasi dari penanam kopi (-1). Seperti kutipan berikut, "...Anggota mah kurang tahu...terus sebagian mereka kan emang keluarga..." (Wawancara INF46 yang dilakukan pada tanggal 5 Februari 2021 pada pukul 09.00 - 10.00 WIB) dan “... Ya biasanya (yang mengikuti kegiatan) adalah salah satu pengurus, saya, sama Pak O..." (Wawancara INF36 yang dilakukan pada tanggal 3 Februari 2021 pada pukul 08.00 - 09.00 WIB).

Faktor kedua buruknya akses I\&P muncul justru dari aspek non-SRAM yaitu komunikasi dengan nilai agregat (-4) yang juga dilakukan oleh pengurus LMDH Rawa Sakti. Berdasarkan data di lapangan anggota LMDH Rawa Sakti memiliki informasi yang lawas dan kurang mengetahui informasi terkini karena minimnya kegiatan bersama yang dianggap kurang efektif oleh pengurus LMDH Rawa Sakti. Seperti beberapa kutipan berikut: “...ada apaapa nggak dikasih tau malah Mas..." (Wawancara INF47 yang dilakukan pada tanggal 5 Februari 2021 pada pukul 11.00-12.00 WIB), “... Tidak ada (omongan). Kalau ada tujuan apa-apa Pengurus juga diem diem aja..." (Wawancara INF52 yang dilakukan pada tanggal 6 Februari 2021 pada pukul 08.00 - 09.00 WIB), dan “...Jarang sekali mas. Udah lama sekali tidak ada rapat-ratap gitu. Terakhir itu pas sertifikat..." (Wawancara INF39 yang dilakukan pada tanggal 3 Februari 2021 pada pukul 14.00 - 15.00 WIB).

Sedangkan agregat positif terbesar akses informasi adalah terhadap akses pasar yang hanya memiliki jumlah agregat (+3) yang dimiliki oleh para Bakul (tengkulak) untuk mencari tahu harga dalam menjual komoditas

Pembahasan terakhir dalam bagian ini adalah melihat akses pasr, maka jika dilihat dari Gambar 1 terdapat tiga akses yang memiliki agregat positif yaitu NHS (+29), I\&P (+3), dan Otoritas $(+1)$. Berdasarkan data lapangan ternyata akses pasar sangat dipengaruhi oleh akses NHS, dimana pemasaran dari hasil komoditas yang ditanam oleh anggota dijual kepada Bakul (tengkulak) yang memang sudah dikenal oleh anggota LMDH Rawa Sakti. Pada sisi lainnya, pemasaran sangat memerlukan NHS yang diterapkan oleh pengusaha kopi untuk menjual komoditas kepada kenalannya 
seperti aparat pemerintah, mahasiswa, dan warga sekitar. Berikut kutipan penggunaan NHS sebagai alat untuk pemasaran oleh INF34, “...awalnya dibeli oleh Dinas... Nah di sana ada orang-orang dinas yang membeli kopi saya terus mungkin mereka kasihkan ke kenalankenalan mereka Mas..." (Wawancara INF34 yang dilakukan pada tanggal 2 Februari 2021 pada pukul 11.10-12.15 WIB).

\section{Akses Tenaga Kerja}

Sedikit berbeda dengan Ribot dan Peluso (2003) yang menyebutkan bahwa akses tenaga kerja harus memiliki dua akses utama yaitu akses modal dan akses pasar. Temuan dalam penelitian ini justru akses tenaga kerja paling besar bersumber dari akses otoritas dengan nilai agregat $(+12)$ seperti pada gambar 2 . Akses tenaga kerja yang ditemukan oleh penulis utamanya dilakukan oleh Perum Perhutani pada konteks belum adanya SK Kulin KK seperti kutipan berikut, "...Awal mulanya itu ikut garap dan nyadap karena memang deket sama orang perhutani dan ditawarin..." (Wawncara INF48 yang dilakukan pada tanggal 5 Februari 2021 pada pukul 13.00 - 14.00 WIB), “...Ya ikut garap kaya INF54, dari mandor terus disuruh saling jaga saya garap dan menjaga juga pinusnya..." (Wawancara INF55 yang dilakukan pada tanggal 6 Februari 2021 Pada pukul 15.00 - 16.00 WIB).
Didapatkan informasi bahwa informan anggota LMDH Rawa Sakti dapat memanfaatkan kawasan hutan atas izin dari petugas Perum Perhutani (akses otoritas). Namun di sisi lainnya, pemberian izin atas dasar akses otoritas ini diikuti tanggung jawab untuk sukarela membantu pekerjaan petugas Perum Perhutani (akses tenaga kerja), terdapat ancaman atau intimindasi pencabutan izin pemanfaatan bagi informan yang enggan membantu pekerjaan Perum Perhutani seperti kutipan berikut, "...Dulu kalau nggak ikut apa kata orang perhutani itu bakal diintimindasi kalau nggak ikut katanya tidak boleh kelola hutan lagi..." (Wawancara INF42 yang dilakukan pada tanggal 4 Februari 2021 pada pukul 9.30-10.30 WIB).

Kemudian sejalan yang disebutkan dengan Ribot dan Peluso (2003), akses tenaga kerja juga muncul akibat kesiapan modal $(+4)$ dan NHS (+2) yang dimiliki pengurus untuk memperkerjakan beberapa informan anggota dalam usaha pribadi dari pengurus atau bahkan dulu oleh Perum Perhutani. Seperti pernyataan yang disampaikan INF51 (Wawancara yang dilakukan pada tanggal 6 Februari 2021 pada pukul 10.00 - 11.00 WIB) yang diberikan uang kerja sekitar Rp.50 ribu dan rokok dalam menjalankan tugasnya.

\section{Akses Tenaga Kerja}

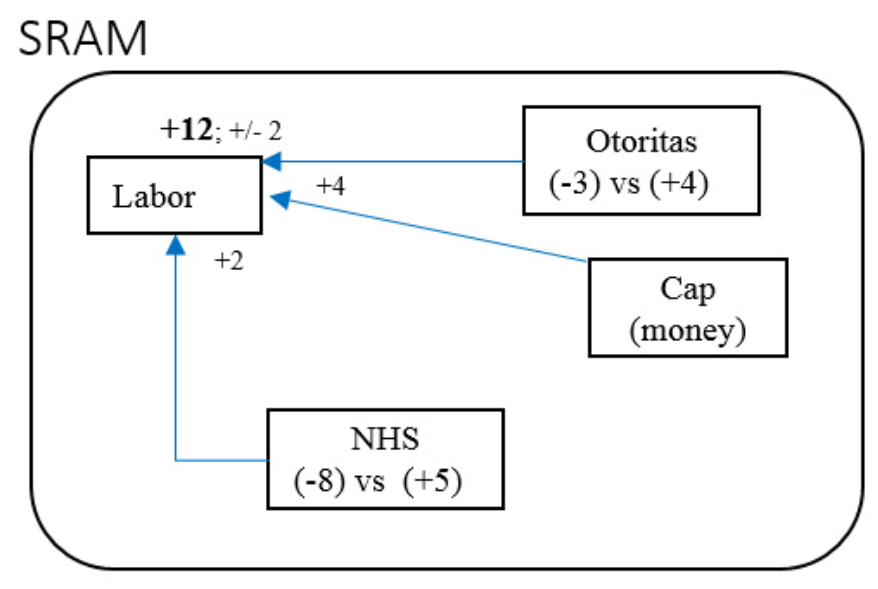

Gambar 2.

Pemetaan Agregat Akses Tenaga Kerja (Labor)

Sumber: data primer yang diolah penulis, tahun? 


\section{Akses Otoritas}

Terdapat beberapa akses yang dipengaruhi oleh akses otoritas dari kasus LMDH Rawa Sakti yang bersifat positif atau negatif, baik yang SRAM atau non-SRAM. Jika dilihat dari Gambar 3, terdapat hanya satu akses yang dipengaruh baik positif atau negatif yaitu akses modal non uang (Cap not money) dengan nilai agregat +41 dan -3 . Agregat +41 pada akses modal non uang (lahan garapan) adalah agregat tertinggi dari akses otoritas yang muncul dari Perum Perhutani (+28) dan LMDH Rawa Sakti (+13). Kebanyakan dari informan di LMDH Rawa Sakti sebelum adanya SK PS dapat mengakses modal bukan uang yaitu lahan atas dasar "izin" dari petugas Perum Perhutani, seperti kutipan berikut, "...Jadi awalnya itu ikut-ikut nguli oleh mandor disuruh nanem pinus dipelihara...." (Wawancara INF47 yang dilakukan pada tanggal 5 Februari 2021 pada pukul 11.00-12.00 WIB), dimana sekarang dengan adanya SK PS sebagai dasar akses otoritas LMDH Rawa Sakti mengelola Kawasan hutan, sekarang informan anggota dapat lebih leluasa menanam di kawasan hutan seperti kutipan berikut, "Dulu itu kalua nenamnanem itu kita takut Mas. Takut dimarahin sama mandor. Tapi setelah ada sertifikat akhirnya boleh nanem dari pada lahan hutan nggak pake udah gitu masa waktunya kita 35 tahun..." (Wawancara INF37 yang dilakukan pada tanggal 3 Februari 2021 pada pukul 18.00 - 19.00 WIB).

Agregat positif kedua terbesar dari akses otoritas adalah akses tenaga kerja yang telah dijelaskan pada bagian sebelumnya. Sisanya agregat positif dari akses otoritas bernilai +4 untuk akses otoritas itu sendiri, +2 yaitu pada akses pasar (Mrkt), teknologi (Tec). Adanya dampak positif dari akses otoritas mengarah pada akses otoritas itu sendiri lebih mengarah pada semakin besarnya ruang bagi masyarakat dalam mengelola hutan yang sudah tidak cemas dari kehadiran para petugas Perum Perhutani yang dapat mengintimindasi seperti di masa lalu (Wawancara INF42 yang dilakukan pada tanggal 4 Februari 2021 pada pukul 9.30-10.30 WIB dan Wawancara INF56 yang dilakukan pada tanggal 8 Februari 2021 pada pukul 13.00 - 14.00 WIB)

Pada sisi agregat negatif, maka akses otoritas nilai agregat negatif terbesar pada I\&P yang sudah dijelaskan pada bagian sebelumnya. Kemudian agregat negatif terbesar kedua dari akses otoritas mengarah pada akses NHS dengan nilai -7 terjadi akibat hubungan yang menekankan pada hak dari pada kewajiban dari Perum Perhutani terhadap LMDH Rawa Sakti (-4) dan kurangnya perhatian desa terhadap LMDH akibat hubungan sosial yang terjadi selama ini (-3). Hubungan yang mengarah pada penekanan hak Perum Perhutani kepada LMDH Rawa Sakti dapat dilihat dalam kutipan berikut:

"...selama ini baru didapatkan dua kali sharing hasil hutan yang pertama itu sebesar Rp.300 ribu rupiah untuk tahun 2015-an yang dibayarkan tahun 2017, dan kedua itu sebesar Rp. 5 juta rupiah untuk tahun 2016 yang dibayarkan tahun 2018 yang selebihnya hingga tahun ini tidak ada "share" dari Perhutani... Sedangkan INF30 pernah membayarkan Rp.12,7 juta pada tahun 2016, Rp.5 juta pada tahun 2017, Rp.2-3 jutaan pada tahun

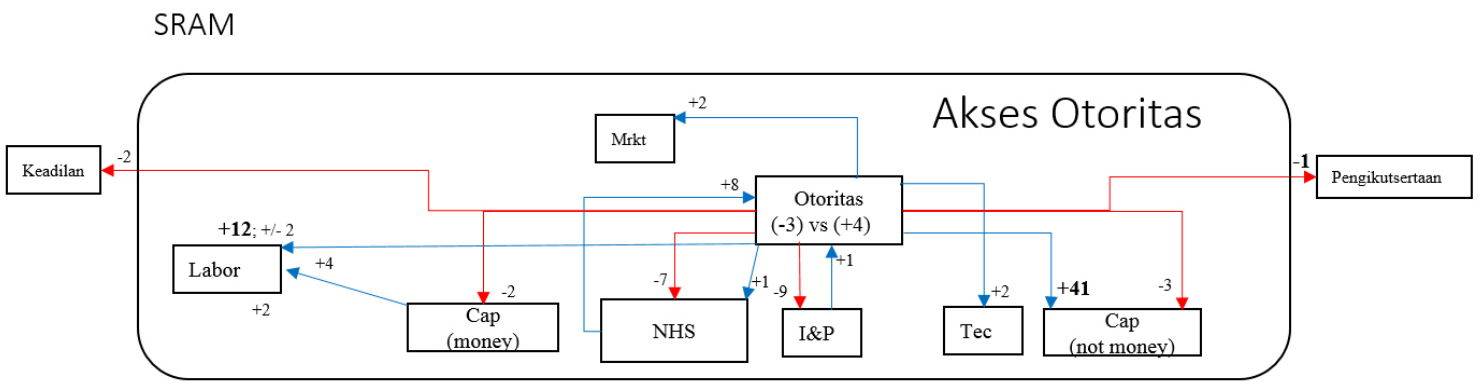

Gambar 3.

Pemetaan Agregat Akses Otoritas

Sumber: data primer yang diolah penulis, tahun? 
2018..." (Wawancara INF30 yang dilakukan pada tanggal 31 Januari 2021).

Agregat negatif juga muncul pada unsur non-SRAM yaitu pada keadilan (-2) karena adanya tindakan pilih kasih oleh oknum dari Perum Perhutani terkait penanaman cabai oleh masyarakat dan minimnya pendampingan Perhutani terhadap LMDH RS. Pada aspek pengikutsertaan dengan nilai agregat (-1) terjadi akibat minimnya tanggung jawab Perhutani terhadap LMDH RS.

Kemudian jika berdasarkan pada teori akses itu sendiri, sedikit berbeda dengan Ribut dan Peluso (2003) maka terdapat akses modal (non-uang) yang tidak menekankan pada kemampuan finansial tetapi menekankan pada sesuatu yang dapat dimanfaatkan untuk memperoleh modal. Lebih lanjut ternyata akses modal non-uang ini yang dapat dipengaruhi utamanya dari akses otoritas.

\section{Akses Modal Uang dan Non-Uang}

Melanjutkan pembahasan terkait akses modal non-uang, maka pada bagian ini terlihat ternyata bukan hanya akses otoritas saja yang memiliki agregat positif pada akses non uang. Akses NHS adalah akses dengan nilai agregat terbesar kedua setelah akses otoritas pada akses modal non uang dengan nilai agregat +20 yang bersumber dari LMDH Rawa Sakti. Berkat adanya sertifikat kemitraan antara LMDH Rawa Sakti dari KLHK, menjadikan anggota LMDH dapat mengelola hutan sebagai lahan garapan (akses modal non uang). Disamping LMDH Rawa Sakti adalah identitas dengan nilai agregat $(+3)$. Gambar dari pemetaan agregat akses modal (uang dan non uang) dapat dilihat pada gambar 3, sebagai berikut.

Dalam identifikasi agregat memang tidak dijelaskan secara eksplisit dalam skema bahwa akses modal non-uang memiliki agregat positif terhadap akses kapital atau uang. Namun berdasarkan perhitungan kasar yang dilakukan penulis berdasrakan data yang didapat dari para informan anggota didapatkan bahwa rata-rata pendapatan anggota dari menanam di kawasan hutan \pm Rp.655.804/tanam dengan nilai standar deviasi yaitu Rp.1.468.545,-/ tanam.

Kecilnya jumlah rata-rata karena memang terdapat beberapa informan yang merugi menanam di hutan disamping kondisi lahan yang kurang memungkinkan menanam tanaman semusim akibat rimbunnya pohon pinus. Beberapa dari informan ada yang akhirnya membiarkan lahan garapan atau minimal menanam singkong yang dipanen setahun sekali dengan keuntungan

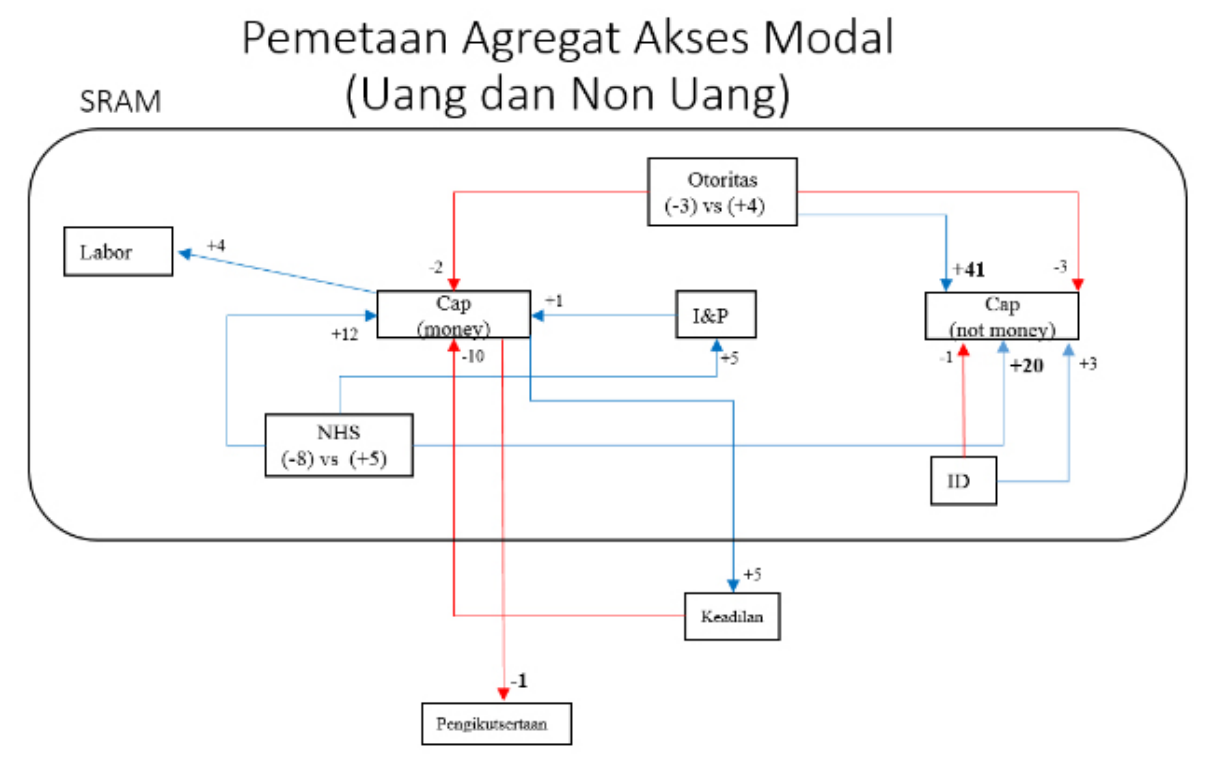

Gambar 4

Pemetaan Agregat Akses Modal Uang dan Non Uang

Sumber: data primer yang diolah penulis, tahun? 
Rp.200.000,-/ tanam dengan sistem panen yang diambil oleh tengkulak (borongan).

Kondisi tersebut sedikit berbeda dengan akses non uang, maka akses modal (uang) dipengaruhi utamanya oleh akses NHS dengan nilai agregat $(+12)$. Akses modal yang dimaksud adalah akses modal untuk memulai bertani dalam menggarap lahan di kawasan hutan. Terdapat pihak-pihak dari kenalan informan yang dapat menjadi sumber modal seperti keluarga secara umum (Wawancara INF37yang dilakukan pada tanggal 3 Februari 2021 pada pukul 18.00 - 19.00 WIB), orang tua (Wawancara INF35yang dilakukan pada tanggal 2 Februari 2021 pada pukul 19.2020.21 WIB), anak (Wawancara INF52 yang dilakukan pada tanggal 6 Februari 2021 pada pukul 08.00 - 09.00 WIB), kerabat atau saudara (INF30) bahkan kenalan (Wawancara INF35 yang dilakukan pada tanggal 2 Februari 2021 pada pukul 19.20-20.21 WIB). Dimana ternyata kegiatan pertanian dilakukan oleh para informan anggota LMDH Rawa Sakti cenderung dilakukan secara sendiri-sendiri.

Kemudian, terdapat agregat negatif dengan nilai yang menyaingi agregat positif senilai (-10) terhadap akses modal/uang dari unsur non-SRAM yaitu keadilan. Sangat disayangkan ternyata yang menghalangi akses modal (uang) kembali dilakukan oleh pengurus yang pertama adalah membatasi anggota untuk mencari keuntungan dari usaha yang dilakukan bersama dahulu (-7), menyulitkan anggota dan pengurus lainnya yang ingin membuka usaha di tempat yang berbeda (-2), dan hal tersebut dirasakan sebagai bentuk ketidakadilan dari pengurus terhadap beberapa anggota dan pengurus lainnya (-1). Bentuk ketidakadilan terhadap akses ekonomi dapat dilihat dari kutipan berikut: "...Sekarang dimananpun mau mendirikan usaha itu katanya harus izin ke informan pengurus. Dia itu udah bilang "tanpa izin dari dia" tidak akan bisa. Padahal pemimpin harusnya mengayomi kan Mas..." (Wawancara INF46 yang dilakukan pada tanggal 5 Februari 2021 pada pukul 09.00 - 10.00 WIB).

Terakhir untuk bagian modal, dapat dilihat akses modal memiliki agregat positif pada "labor" dengan nilai $(+4)$ yang merefleksikan adanya kegiatan, KUPS, dan perhutani sehingga LMDH Rawa Sakti dapat memperkerjakan beberapa anggota dari kegiatan wisata yang ada.

Berdasarkan hal tersebut jika dikaitkan dengan akses informasi yang juga dikuasai oleh beberapa anggota utamanya dekat dengan salah satu pengurus ini disertai pembatasan akses ekonomi bagi beberapa anggota dan pengurus lainnya, maka terdapat indikasi elite capture yang terjadi di LMDH Rawa Sakti. Adanya indikasi elite capture ini yang memang terobservasi ketika dilakukannya kegiatan Focus Group Disccussion (Kegiatan FGD yang dilakukan pada tanggal 8 Februari 2021 padapukul 19.49 - 21.10 WIB), dimana salah satu pengurus menjabarkan berbagai macam rencana kegiatan yang mengatasnamakan LMDH Rawa Sakti ternyata rencana tersebut baru diketahui di saat itu juga oleh anggota yang mengikuti kegiatan FGD.

Bagian selanjutnya akan dijabarkan akses negosiasi dan hubungan sosial (NHS) yang lebih lanjut sedikit diulas tentang elite capture yang terjadi di LMDH Rawa Sakti. Berikut akan digambarkan pemetaan agregat akses NHS:

\section{Akses Negosiasi dari Hubungan Sosial (NHS)}

Jika dilihat dari Gambar 5, maka dapat dilihat bahwa akses NHS memiliki banyak agregat ke unsur SRAM lainnya baik positif atau negatif. Akses NHS yang bersifat positif pada akses SRAM lainnya konteks LMDH Rawa Sakti yaitu seperti akses pasar (+29), akses modal non uang $(+20)$, akses uang $(+12)$, akses I\&P (+5) dan akses tenaga kerja $(+2)$. Keempat unsur SRAM lainnya tersebut sudah dijelaskan pada bagian-bagian sebelumnya.

Berdasarkan hal tersebut maka jika dibandingkan dengan akses lainnya, akses NHS adalah akses yang esensial karena dapat mengarah ke lima (5) akses SRAM lainnya dengan sifat positif. Hal ini sejalan dengan premis yang disampaikan oleh Ribot dan Peluso (2003) dimana akses NHS adalah akses yang penting di dalam analisis teori akses. 


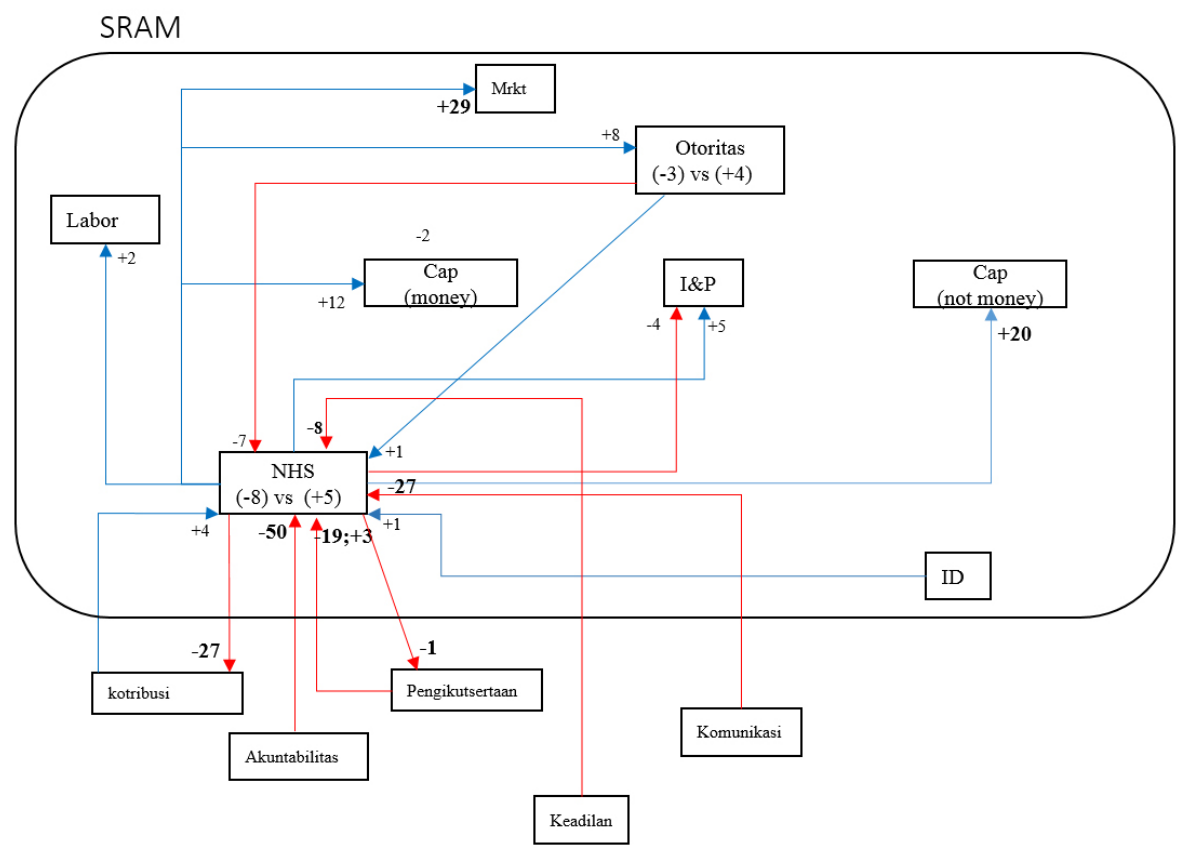

Gambar 5.

Pemetaan Agregat Akses Negosiasi dan Hubungan Sosial (NSH)

Sumber: data primer yang diolah penulis, tahun?

Pada agregat negatif akses NHS memilikinya dalam lingkup akses SRAM lainnya khususnya I\&P (-4). Kemudian, terdapat dua (2) unsur SRAM lainnya yang memiliki agregat positif dan atau negatif terhadap akses NHS yaitu akses identitas $(+1)$ dan akses otoritas (+1/-7). Nilai agregat (-7) dari akses otoritas ke akses NHS telah dijelaskan pada bagian sebelumnya.

Setelah kita melihat lingkup akses SRAM yang ditawarkan oleh teori akses dari Ribot dan Peluso (2003), hal yang menarik dari gambar 5, menunjukan justru tingginya angka-angka agregat terhadap akses NHS justru muncul dari unsur non-SRAM. Lebih banyak dari agregat unsur SRAM sendiri kepada akses NHS, kelima akses non-SRAM memiliki agregat positif dan negatif yang jauh lebih besar.

Nilai agregat terbesar dari non-SRAM terhadap akses NHS paling tinggi justru muncul dari akuntabilitas (-50), komunikasi (-27), pengikutsertaan (-19), dan keadilan (-8), hanya unsur kontribusi dari non-SRAM yang memiliki agregat positif terhadap akses NHS $(+4)$. Banyaknya agregat negatif dari unsur
non-SRAM yang bersumber dari CA akan dijabarkan pada paragraf selanjutnya.

Besarnya nilai agregat negatif terhadap akses NHS dari akuntabilitas didasarkan pengalaman-pengalaman anggota atau pengurus lain terhadap terjadinya elit capture oleh salah satu pengurus di LMDH Rawa sakti (-20). Hal tersebut didasarkan pengalaman pada penguasaan otoritas oleh sang elite $(-8)$, penguasaan sumber ekonomi (-5), pembatasan izin membuka usaha baru di lingkup LMDH Rawa Sakti (-2), penguasaan pengetahuan (-1), perubahan data (-1), penyebaran isu bahwa sang elit tidak bisa digantikan (-1), pengabaian terhadap permintaan anggota (-1), dan pengarahan kepada anggota ketika dilakukan rapat dengan pihak dari luar kelompok (-1).

Buruknya akuntabilitas pada pengelola LMDH Rawa Sakti dapat dilihat dari kutipan berikut:

“...salah satu pengurus itu seperti memiliki LMDH sendiri..." (Wawancara INF49 yang dilakukan pada tanggal 5 Februari 2021 pada pukul $15.00-16.00 \mathrm{WIB}$ ) 
"...Pas pemetaan juga itu Mas diubah. Yang bale gandrung itu sebenarnya ada Garapangarapan orang lain, tapi dibah jadi garapanya dia yang kemudian masuklah keluarganya salah satu pengurus ke dalam SK LMDH...Dulu juga waktu kumpul-kumpul gitu sudah diarahkan oleh salah satu pengurus..." (Wawancara INF46 yang dilakukan pada tanggal 5 Februari 2021 pada pukul 09.00 - 10.00 WIB).

Buruknya akuntabilitas sangat terkait dengan pengurus dari LMDH Rawa Sakti yaitu Disebabkan karena ketidakpercayaan anggota kepada pengurus untuk menyetorkan hasil bumi dari lahan garapan di hutan (-11), terjadinya kolusi (-8) yang memberikan manfaat seperti lahan garapan dan pengetahuan kepada orang-orang terdekat pengurus, buruknya transparansi data dari pengurus LMDH Rawa Sakti ke anggota (-6), dan buruknya komitmen serta tanggung jawab kepada anggota (-4). Sisanya hanya agregat (-1) yang dirasakan pengurus LMDH Rawa Sakti terhadap Perum Perhutani yang dirasakan memberatkan LMDH dari setoran terhadap oknum pada konteks sebelum adanya SK Kulin KK.

Ekspresi-ekspresi ketidakpercayaan tersebut dapat dilihat dari kutipan-kutipan berikut:

"...Kemudian ada kecurigaan yang dimiliki "sebagian" anggota terhadap kelompok.... Waktu itu ada di bidang agroforestry ketika panen itu komoditasnya kopi dan kami minta share. Tetapi ada anggota yang menyatakan "...saya tidak percaya pada pengurus"... Jadi ada pengalaman anggota yang merasa dibohongi katanya ada investasi dan ternyata pengurus tidak amanah" (Wawancara INF32 yang dilakukan pada tanggal 1 Februari 2021 pada pukul 15.00 16.00 WIB)

"...Ada juga buat uang jaga malam sekitar 100 rb/bulan tapi hasilnya hilang dan nggak ada tanggung jawabnya..." (Wawancara INF46 yang dilakukan pada tanggal 5 Februari 2021 pada pukul 09.00 - 10.00 WIB)

"...Ya dampaknya suuuzan. Ya kalau kita gak sabar bisa berantem Mas... Jadi kita itu udah tanam terus aktanya mau diganti tanamannya ditanam yang lain. Tapi kan orangnya gak mau. Jadi suudzan..." (Wawancara INF47 yang dilakukan apda tanggal 5 Februari 2021 pada pukul 11.00 - $12.00 \mathrm{WIB}$ )
“...Kelola bareng-bareng itu nggak jelas hasilnya berapa. Kalau yang ngatur jujur ya mau... Denger-denger sih begitu (terdapat keraguan terhadap pengelola LMDH)..." (Wawancara INF53 yang dilakukan pada tanggal 6 Februari 2021 pada pukul 13.00 - 14.00 WIB)

Pada unsur komunikasi yang mempengaruhi NHS diisi oleh dua unsur yaitu jarangnya kegiatan rutin (-19) yang menjadikan informasi yang dimiliki anggota adalah informasi yang dahulu atau lawas dan ketidakjelasan informasi (-8). Ketidakjelasan informasi seperti terjadi suatu rencana yang akan dilakukan oleh LMDH Rawa Sakti dan sudah mengumpulkan para anggota dan akan dilakukan kegiatan lanjutannya. Namun seiring berjalannya waktu pengurus justru cenderung diam dan tidak membicarakan hal tersebut kepada anggota mengenai rencana dari kegiatan pengumpulan anggota LMDH Rawa Sakti yang telah dilakukan sebelumnya.

Pada unsur pengikutsertaan memang terdapat sebagian informan yang diikutsertakan dalam kegiatan sehingga terdapat nilai (+3) yang mengarah ke akses NHS. Namun nilai terbanyak justru bersifat negatif pada agregat pengikutsertaan kepada akses NHS yang utamanya terjadi akibat kegiatan yang individualis (-18). Baik pengurus dan anggota LMDH Rawa Sakti cenderung menyebutkan memang kegiatan penggarapan di kawasan hutan dilakukan secara individualis.

Hal ini dapat dikaitkan dari nilai agregat negatif terbesar dari NHS ke unsur non-SRAM yaitu "komunikasi" dan "kontribusi" (-27). Jika kita melihat bahwa jarang adanya kegiatan rutin dan informasi yang ada tidak jelas ditambah dengan kegiatan yang individualis, maka menjadi banyak agregat pada unsur kontribusi yang menyatakan bahwa cenderung belum ada sharing (-23) atau penyerahan sebagian hasil bumi dari anggota kepada Perum Perhutani melalui lembaga LMDH Rawa Sakti. Kalau pun ada itu hanya beberapa kali (-4).

Minimnya kontribusi yang terjadi dari para anggota kepada pengurus LMDH Rawa Sakti juga diperkuat dari ketidakpercayaan (-11) anggota kepada pengurus LMDH Rawa Sakti. Karena memang pengalaman beberapa 
anggota dan isu tersebut menyebar di anggota LMDH Rawa Sakti yang juga diketahui oleh Perum Perhutani.

Terakhir agregat negatif terendah dari unsur non-SRAM kepada akses NHS muncul dari unsur keadilan (-8). Banyaknya agrega dari ketidakadilan ini muncul dari terdapatnya kecenderungan orang-orang yang mendukung pengurus yang terindikasi "elite capture" yang diikutsertakan dalam kegiatan LMDH Rawa Sakti. Pengalaman tersebut disebutkan oleh informan anggota yang menyatakan bahwa sempat pada awalnya diikutsertakan namun setelah menyampaikan argumennya yang tidak sejalan dengan pengurus yang terindikasi "elite capture", maka sang anggota tersebut tidak diajak kembali mengikuti kegiatan kelompok. Pada bagian selanjutnya akan sedikit dijelaskan indikasi "elite capture" yang terjadi di LMDH Rawa Sakti.

\section{Elite Capture yang terjadi pada LMDH Rawa Sakti}

Pengurus LMDH Rawa Sakti cenderung menjaring informasi dengan cara blusukan atau kegiatan mencari tahu informasi secara langsung di lapangan terhadap anggota dengan asumsi bahwa "...terdapatnya 10 orang di dalam rapat, maka akan ada 10 kepala...". Kemudian berdasarkan hasil observasi dalam kegiatan FGD terlihat pengurus LMDH sangat mendominasi diskusi dimana terdapat satu kegiatan yang mengatasnamakan kelompok oleh pengurus ternyata baru didengar dan didiskusikan dengan para anggota di dalam kegiatan FGD. Pengatasnamaan ini yang cenderung mengarah pada elite capture dimana sang elit cenderung memposisikan diri sebagai pembuat keputusan (Moeliono et al., 2017), padahal sangat penting untuk mendiskusikan suatu kegiatan sebelum dilaksanakan mulai dari perencanaan (Mohammed, Inoue dan Shivakoti, 2017; Essougong, FoundjemTita dan Minang, 2019). Fakta tersebut juga merefleksikan ketimpangan informasi yang dapat mengarah pada ketimpangan distribusi manfaat lanjutannya (Moeliono et al., 2017; Pujo et al., 2018; Qurniati et al., 2019).
Selain timpangnya distribusi informasi, terdapat juga ketimpangan pengikutsertaan terhadap pengurus lainnya jika terdapat kegiatan rutin (Wawancara INF46 yang dilakukan pada tanggal 5 Februari 2021 pada pukul 09.00 - 10.00 WIB dan Wawancara INF48 yang dilakukan pada tanggal 5 Februari 2021 pada pukul 13.00 - 14.00 WIB), dimana beberapa informan anggota lainnya yang dulu pernah mengikuti rapat kini tidak diikutsertakan karena bertentangan atau tidak setuju dengan keputusan salah satu pengurus (Wawancara INF46 yang dilakukan pada tanggal 5 Februari 2021 pada pukul 09.00 - 10.00 WIB; Wawancara INF47 yang dilakukan pada tanggal 5 Februari 2021 pada pukul 11.00-12.00 WIB; Wawancara INF53 yang dilakukan pada tanggal 6 Februari 2021 pada pukul 13.00 - 14.00 WIB).

Kondisi ini diperburuk dengan aspek nonSRAM yaitu akuntabilitas yang yang tercerim dari ungkapan salah informan anggota yang kurang percaya terhadap pengurus yang dirasa mau menang sendiri (Wawancara INF32 yang dilakukan pada tanggal 1 Februari 2021 pada pukul 15.00 - 16.00 WIB; Wawancara INF52 yang dilakukan pada tanggal 6 Februari 2021 pada pukul 08.00 - 09.00 WIB; Wawancara INF53 yang dilakukan pada tanggal 6 Februari 2021 pada pukul 13.00 - 14.00 WIB; Wawancara INF49 yang dilakukan pada tanggal 5 Februari 2021 pada pukul15.00-16.00WIB). Maka dariitu ketidakpercayaan antara informan anggota dan pengurus ini yang mengarah pada keengganan untuk mengikuti kegiatan bersama sekaligus meningkatkan perasaan lebih aman untuk melakukan penggarapan kawasan hutan secara individualis, hal ini yang tidak dijelaskan oleh Moeliono et al. (2017). Padahal akuntabilitas dan pembangunan kepercayaan adalah aspek yang mendasar dalam pembangunan kapasitas komunitas (Moeliono et al., 2017; Kelly, 2018; Pujo et al., 2018; Weissberg, Kusel dan Rodger, 2018; Wulandari dan Inoue, 2018; Essougong, Foundjem-Tita dan Minang, 2019; Rakatama dan Pandit, 2020).

Sisanya, keegosian dari pengurus yang memberikan manfaat lebih bagi keluarganya khususnya pada proses pembuatan SK LMDH yang merefleksikan penggunaan 
akses otoritas dan informasi oleh pengurus untuk memberikan manfaat lebih bagi orangorang yang ada disekitarnya yang sejalan dengan elite capture. Selain itu juga elite capture terjadi pada penguasaan kegiatan ekonomi dan penghambatan bagi anggota yang tidak sejalan oleh pengurus yang jika dilihat dari teori akses maka pengurus menggunakan akses otoritasnya untuk meningkatkan akses modal yang dimilikinya, namun sisi lain membatasi dan menghalangi akses modal terhadap pengurus dan anggota lainnya. Sehingga permasalahan yang utama dari pengelolaan sumber daya hutan pada kasus LMDH Rawa Sakti adalah pada permasalahan internal khususnya hubungan antara pengurus dan anggota yang didalamnya terdapat dinamika struktur-proses.

\section{SIMPULAN}

Sejalan dengan penelitian sebelumnya, teori akses dapat melihat seperti apa dinamika struktur dan agen di dalam pendistribusian sumber daya pada kasus ini yang terjadi di LMDH Rawa Sakti. Namun terdapat beberapa aspek yang kurang dilihat oleh Ribot dan Peluso (2003) dari kerangka pikir teori akses SRAM dimana ternyata modal tidak selalu berbentuk uang tetapi juga dapat berupa lahan garapan pada konteks LMDH Rawa Sakti. Kemudian akses tenaga kerja yang tidak harus dibangun oleh akses modal dan akses pasar, karena ternyata akses otoritas juga dapat memiliki pengaruh pada terbukanya akses tenaga kerja.

Kemudian sejalan dengan Ribot dan Peluso (2003) memang hubungan sosial yang dalam SRAM diturunkan menjadi negosiasi dari hubungan sosial (NHS) merupakan unsur yang penting untuk dilihat karena ini berpengaruh pada lima unsur SRAM lainnya baik secara langsung atau tidak langsung kecuali akses identitas. Namun, dinamika di dalam NHS juga perlu dilihat dari aspek Non-SRAM yang dipengaruhi oleh unsurunsur dari collaborative approach (CA) dimana terjadinya elite capture justru membatasi akses anggota lainnya dalam pengimplementasian program PS. Unsur CA yang perlu dilihat dalam hubungan internal kelompok khususnya akuntabilitas, komunikasi dan pengikutsertaan. Ketiga unsur dari CA ini yang menjadi kunci dan penting yang berpengaruh pada unsur kontribusi dan perlu diperhatikan lebih lanjut untuk mengidentifikasi terjadi elite capture baik untuk penelitian selanjutnya atau untuk diimplementasikan.

\section{DAFTAR PUSTAKA}

Asmin, F., Darusman, D., Ichwandi, I., \& Suharjito, D. (2019). Mainstreaming community-based forest management in west sumatra: Social forestry arguments, support, and implementation. Forest and Society, 3(1), 77-96. https://doi.org/10.24259/ fs.v3i1.4047

BPS. (2020). Identifikasi dan Analisis Desa di Sekitar Kawasan Hutan Berbasis Spasial tahun 2019. BPS. https://www.bps.go.id/ publication/download. html? nrbvfeve $=$ ZWU5MjVkM2NkZWJkMzg5 Mjk5YzhkZTc4\&xzmn=aHR0c HM6 L y 93 d 3 c u Y n B z L m d v L mlkL3B1YmxpY2F0aW9uLzIw MjAvMDYvMjkvZWU5MjVkM2N kZWJkMzg5Mjk5YzhkZTc4L2 $1 \mathrm{kZW} 50 \mathrm{aWZpa} 2 \mathrm{FzaS1kYW4t}$ YW5hbGlzaXM tZGVzYS1kaS1zZ WtpdGFyL Wthd2FzYW4t

DS, P. (2020). Kualitas Perhutanan Sosial. Agroindonesia. http:// agroindonesia.co.id/2020/04/ kualitas-perhutanan-sosial/

Essougong, U. P. K., Foundjem-Tita, D., \& Minang, P. A. (2019). Addressing equity in community forestry: Lessons from 20 years of implementation in cameroon. Ecology and Society, 24(1). https://doi. org/10.5751/ES-10656-240109

Firdaus, Y. A. (2018). Panduan Praktis Penerapan Kebijakan Perhutanan Sosial. Panduan Praktis Penerapan Kebijakan Perhutanan Sosial. https:/ / doi.org/10.17528/cifor/006856 
Fisher, M. R., Moeliono, M., Mulyana, A., Yuliani, E. L., Adriadi, A., Kamaluddin, Judda, J., \& Sahide, M. A. K. (2018). Assessing the New Social Forestry Project in Indonesia: Recognition, Livelihood and Conservation? International Forestry Review, 20(3), 346-361. https://doi. org/10.1505/146554818824063014

García-López, G. A., \& Antinori, C. (2018). Between Grassroots Collective Action and State Mandates: The Hybridity of Multi-Level Forest Associations in Mexico. Conservation and Society, 16(2), 193-204. https:// doi.org/10.4103/cs.cs_16_115

Hidayat, H. (2015). Pengelolaan Hutan Lestari: Partisipasi, Kolaborasi dan Konflik ( $\mathrm{H}$. Hidayat (ed.)). Yayasan Pustaka Obor.

Kaskoyo, H., Mohammed, A. J., \& Inoue, M. (2017). Impact of community forest program in protection forest on livelihood outcomes: A case study of Lampung Province, Indonesia. Journal of Sustainable Forestry, 36(3), 250-263. https:/ / doi.org/10.1080/10 549811.2017.1296774

Kelly, E. C. (2018). The Role of the Local Community on Federal Lands: the Weaverville Community Forest. Humboldt Journal of Social Relations, 15(40), 163-177. https://www.jstor. org/stable/10.2307/90023270

Kuncoro, M., \& Cahyani, D. (2018). Performance of social forestry on farmers' revenues: lessons from Yogyakartaand Lampung, Indonesia. The Business \& Management Review, 9(4), 275-289.

Massiri, S. D., Malik, A., Golar, Hamzari, \& Nugroho, B. (2020). Institutional capacity of forest management unit in promoting sustainable communitybased forest management. Case study of forest management unit in central sulawesi province,
Indonesia. Jurnal Manajemen Hutan Tropika, 26(2), 169-177. https://doi. org/10.7226/JTFM.26.2.169

Moeliono, M., Thuy, P. T., Bong, I. W., Wong, G. Y., \& Brockhaus, M. (2017). Social forestry-why and for whom? A comparison of policies in vietnam and Indonesia. Forest and Society, 1(2), 78-97. https://doi.org/10.24259/ fs.v1i2.2484

Mohammed, A. J., Inoue, M., \& Shivakoti, G. (2017). Moving forward in collaborative forest management: Role of external actors for sustainable Forest socio-ecological systems. Forest Policy and Economics, 74, 1319. https://doi.org/10.1016/j. forpol.2016.10.010

Myers, R., \& Hansen, C. P. (2020). Revisiting A Theory of Access: A review. Society and Natural Resources, 33(2), 146-166. https://doi.org/10.1080/08941920.2 018.1560522

Nath, T. K., Jashimuddin, M., \& Inoue, M. (2016). Community-Based Forest Management (CBFM) in Bangladesh. In World Forests (Vol. 22, Issue August 2018). https://www.tandfonline. com/doi/full/10.1080/10549811.20 16.1231615

Noveria, M., Mashudi, Gayatri, I. H., \& Mulyani, L. (2005). Hutan, Masyarakat dan Pasar: Usulan Perubahan Paradigma dan Reformasi Kebijakan Sumber Daya Hutan. LIPI Press. http://penerbit. lipi.go.id/penerbitan.cgi?daftar\&11 07298611\&9951\&\&semua

Nurrochmat, D. R., Massijaya, M. Y., Jaya, I. N. S., Abdulah, L., Ekayani, M., Astuti, E. W., \& Erbaugh, J. T. (2019). Promoting community forestry to reduce deforestation surrounding Gunung Rinjani National Park in Central Lombok, Indonesia. IOP Conference Series: Earth and Environmental Science, 285(1). 
https:// doi.org/10.1088/17551315/285/1/012014

Pambudi, A. S. (2020). The Development of Social Forestry in Indonesia: The Journal of Indonesia Sustainable Development Planning, 1(1), 57-66. https://doi.org/10.46456/jisdep. v1i1.11

Peluso, N. L., \& Ribot, J. (2020). Postscript: A Theory of Access Revisited. Society and Natural Resources, 33(2), 300-306. https://doi.org/10.1080/08941920.2 019.1709929

Pujo, Sofhani, T. F., Gunawan, B., \& Syamsudin, T. S. (2018). Community capacity building in social forestry development: A review. Journal of Regional and City Planning, 29(2), 113-126. https://doi.org/10.5614/ jrcp.2018.29.2.3

Qurniati, R., Darmawan, A., Utama, R. B., \& Inoue, M. (2019). Poverty distribution of different types of forest-related communities: Case study in Wan Abdul Rachman forest park and mangrove forest in Sidodadi Village, Lampung Province, Indonesia. Biodiversitas, 20(11), 3153-3163. https:/ / doi.org/10.13057/biodiv/ d201107

Rachmawan, D. (2020). Focus Group Discussion dengan KLHK.

Rakatama, A., \& Pandit, R. (2020). Reviewing social forestry schemes in Indonesia: Opportunities and challenges. Forest Policy and Economics, 111(1), 102052. https://doi.org/10.1016/j. forpol.2019.102052

Ribot, Jesse, C., \& Peluso, Nancy, L. (2003). A Theory of Access *. Rural Sociology, 68(2), 153-181.

Royer, S. De, Noordwijk, M. Van, \& Roshetko, J. M. (2018). Does communitybased forest management in Indonesia devolve social justice or social costs? International Forestry
Review, 20(2), 167-180. https://doi. org/10.1505/146554818823767609

Santika, T., Wilson, K. A., Budiharta, S., Kusworo, A., Meijaard, E., Law, E. A., Friedman, R., Hutabarat, J. A., Indrawan, T. P., St. John, F. A. V., \& Struebig, M. J. (2019). Heterogeneous impacts of community forestry on forest conservation and poverty alleviation: Evidence from Indonesia. People and Nature, 1(2), 204-219. https://doi.org/10.1002/pan3.25

Sardjono, M. A., \& Inoue, M. (2017). Collaborative Governance of Forest Resources in Indonesia: Giving Over Managerial Authority to Decision Makers on the Sites. In Redefining Diversity and Dynamics of Natural Resources Management in Asia (Vol. 1, Issue 2013). Elsevier Inc. https:/ / doi.org/10.1016/B978-0-12-8054543.00011-6

Setiajiati, F., Karyaatmadja, B., Sutedja, I., Kuswondho, H., Satria, P., Sejati, \& Maharani, R. S. (2019). Lesson Learned from Social Forestry Practice in a Forest and Climate Change Project in Kalimantan, Indonesia. IOP Conference Series: Earth and Environmental Science, 363(1). https:// doi.org/10.1088/17551315/363/1/012001

Shohibuddin, M. (2018). Perspektif Agraria Kritis: Teori, Kebijakan dan Kajian Empiris. March, lxiv + 233.

Suparno, R., Nurbaiti, A., Afiff, S., Tarmizi, H., Mariani, E., \& Sastriastanti, F. (2018). Toward Just and Sustainable Forestry in Indonesia. In R. Suparno \& A. Nurbaiti (Eds.), Riyadi Suparno Ati Nurbaiti Suraya Afiff Hendarsyah Tarmizi Evi Mariani Fidelis Sastriastanti. The Jakarta Post Publishing. http://silk.dephut. go.id/app/Upload/repos/201906 25/2b5976ba1ae096fb4ac1fd33bce5 be00.pdf 

pada Konteks Program Perhutanan Sosial: Studi Kasus Lembaga Masyarakat Desa Hutan...

Susilo, Y. S., \& Nairobi. (2019). Dampak Perhutanan Sosial Terhadap Pendapatan Masyarakat (The Impact of Social Forestry on Community Incomes). Jurnal ISEI Economic Review, III(1), 16-27.

UNESA. (2019). UN Strategic Plan for Forests 2030.

Voo, P., Mohammed, A. J., \& Inoue, M. (2016). Community Use Zone (CUZ) Model and Its Outcome in Malaysia Case Study from Crocker Range Park, Sabah. Journal of Management and Sustainability, 6(3), 25. https:// doi.org/10.5539/jms.v6n3p25

Weissberg, L. M., Kusel, J. P., \& Rodger, K. A. (2018). From conflict to collaboration. Humboldt Journal of Social Relation,
40(40), 178-190. https://www.jstor. org/stable/10.2307/90023271

Wright, G. D., Andersson, K. P., Gibson, C. C., \& Evans, T. P. (2016). Decentralization can help reduce deforestation when user groups engage with local government. Proceedings of the National Academy of Sciences of the United States of America, 113(52), 14958-14963. https://doi. org/10.1073/pnas.1610650114

Wulandari, C., \& Inoue, M. (2018). The Importance of Social Learning for the Development of Community Based Forest Management in Indonesia: The Case of Community Forestry in Lampung Province. Small-Scale Forestry, 17(3), 361-376. https:// doi. org/10.1007/s11842-018-9392-7 